\title{
The Effect of Iron on Gluconic Acid Production by Aureobasidium pullulans
}

\author{
Savas Anastassiadis ${ }^{1, *}$, Svetlana V. Kamzolova ${ }^{2}$, Igor G. Morgunov ${ }^{2}$ and Hans-Jürgen Rehm ${ }^{3}$
}

\begin{abstract}
${ }^{I}$ Pythia Institute of Biotechnology, Research in Biotechnology (Co.), Avgi/Sohos, 57002 Thessaloniki, Greece and Environmental Engineering Department of Democritus University of Thrace, 67100 Xanthi, Greece; ${ }^{2}$ Institute of Biochemistry and Physiology of Microorganisms, Russian Academy of Sciences pr-t Nauki 5, Pushchino Moscow Region 142290, Russia and ${ }^{3}$ Institute of Molecular Microbiology and Biotechnology, University of Münster, Corrensstr. 3, 48149 Münster, Germany
\end{abstract}

\begin{abstract}
New processes have been previously described for the continuous and discontinuous production of gluconic acid by Aureobasidium pullulans (de bary) Arnaud. Little is known about the regulatory mechanisms of gluconic acid production by A. pullulans. The response of growth and gluconic acid metabolism to a variable profile of iron concentrations was studied with $A$. pullulans in batch and chemostat cultures. A surprisingly high optimum $\mathrm{N}$-dependent iron ion concentration in the feed medium, in the range between $0.5 \mathrm{mM}$ and $3.0 \mathrm{mM}$ Fe (optimum 1-2 mM), was found to be particular requirement for economically profitable continuous production of gluconic acid with $3 \mathrm{~g} / \mathrm{l} \mathrm{NH} \mathrm{N}_{4} \mathrm{Cl}$. Increased iron concentration promoted growth on defined glucose medium. $223.3 \mathrm{~g} / \mathrm{l}$ gluconic acid were continuously produced at a formation rate of the generic product $\left(\mathrm{R}_{\mathrm{j}}\right)$ of $16.8 \mathrm{~g} /(1 * \mathrm{~h})$ and a specific gluconic acid productivity $\left(\mathrm{m}_{\mathrm{p}}\right)$ of $2.5 \mathrm{~g} /(\mathrm{g} * \mathrm{~h})$ at $13 \mathrm{~h}$ residence time (RT) with $1 \mathrm{mM}$ iron, compared with $182 \mathrm{~g} / 1$ reached at $0.1 \mathrm{mM}$. The product selectivity (product yield based on glucose) increased continuously by raising iron concentration following a saturation curve, reaching a maximum of about $98 \%(\mathrm{~mol} / \mathrm{mol})$ at $2 \mathrm{mM} \mathrm{Fe}$ and $76.2 \%$ conversion, compared with only $84.3 \%$ determined at $0.1 \mathrm{mM}$. The process is not obligatory growth limiting or growth related and residual nitrogen was found in all of continuous experiments, e.g. $197 \mathrm{mg} / \mathrm{l}$ of nitrogen at $0.1 \mathrm{mM}$ and $201 \mathrm{mg} / \mathrm{l}$ at $2 \mathrm{mM}$ of iron.
\end{abstract}

Key Words: Gluconic acid, Aureobasidium pullulans, continuous, continuous fermentation, chemostat, iron effect.

\section{INTRODUCTION}

The physiological D-form of gluconic acid is the oxidation product of glucose usually formed by the microbial oxidation of glucose. Gluconic acid is a colorless, or nearly colorless, light brown syrupy liquid with a mild acid taste. As a multifunctional carbonic acid of great interest, naturally occurring in plants, fruits, wine (up to $0.25 \%$ ), honey (up to $1 \%$ ), rice, meat, vinegar and other natural sources, belonging to the bulk chemicals and due to its versatile physiological and chemical characteristics, gluconic acid (pentahydroxycaproic acid, $\mathrm{C}_{6} \mathrm{H}_{12} \mathrm{O}_{7}$ ) itself, its salts (e.g. alkali metal salts, in especially sodium gluconate) and the gluconolactone form have found extensively various uses in the chemical, pharmaceutical, food and animal feed (improves growth performance), textile, detergent, leather, photographic, construction (it increases cement's resistance against fracture, frost and water) and other biological and chemical industries as well as for analytical purposes [1-7]. Gluconic acid is a mild neither caustic nor corrosive non toxic and readily biodegradable organic acid (98\% after 2 days) with an excellent sequestering power [7].

Numerous gluconic acid manufacturing processes from glucose are described in the international bibliography and

\footnotetext{
*Address correspondence to this author at the Pythia Institute of Biotechnology, Research in Biotechnology (Co.), Avgi/Sohos, 57002 Thessaloniki, Greece and Environmental Engineering Department of Democritus University of Thrace, 67100 Xanthi, Greece; E-mail: sanastassiadis@ @etscape.net
}

patent literature, including chemical and electrochemical catalysis, enzymatic biocatalysis and fermentation processes using bacteria such as Gluconobacter-spec., Pseudomonas, Phytomonas, Achromobacter, Zymomonas mobilis and Acetobacter methanolicus, fungi such as fungi like Aspergillus and Penicillium and yeast-like fungi such as Aureobasidium pullulans (de bary) Arnaud [2, 4, 6-13].

Essentially only Aspergillus niger (predominantly) based on the process developed by [14] or Gluconobacter oxidans have been applied as far for the industrial production of gluconic acid. Alternatively, new superior fermentation processes using Aureobasidium pullulans have been extensively described for the continuous and discontinuous production of gluconic acid by isolated strains of yeast-like mold, which reached gluconic acid concentrations of $230-450 \mathrm{~g} / \mathrm{l}$ at residence times of about 12-20 hours and $504 \mathrm{~g} / \mathrm{l}$ in fed batch mode, offering numerous advantages over the traditional discontinuous fungi processes of the last 100 years. In contrast to A. pullulans the multicellular fungus Aspergillus niger is unsuitable for a continuous production of gluconic acid by free growing cells, whereas Gluconobacter is sensitive to high osmotic pressures and produces a relative large quantity of keto-acids, complicating processing and product recovery $[4,7,15,16$,$] .$

Bioconversion of glucose to gluconic acid is a simple dehydrogenation reaction which takes place without any involvement of complex metabolic pathways. However, numerous parameters influence and regulate gluconic acid pro- 
duction like oxygen, $\mathrm{pH}$, temperature and medium composition $[4,7,17]$.

Glucose in the medium is oxidized extracellularly in a two-step reaction to gluconic acid even in the absence of cells through the action of glucose oxidase and catalase derived from $A$. niger, in where nearly $100 \%$ of the glucose is converted to gluconic acid under the appropriate conditions [18].

Gluconic acid production by A. niger and A. pullulans is a high oxygen ( $>100 \%$ air saturation), $\mathrm{pH}$ ( $\mathrm{pH}$ above 6.5 ) and temperature depending process $\left(30-31^{\circ} \mathrm{C}\right)$, also strongly influenced by the composition of bioreactor medium $[3,4,7$, $13,17,19]$.

Little is known about the regulatory mechanisms of gluconic acid production in $A$. pullulans and regarding the effect of trace elements and other medium compounds on the production of gluconic acid.

The response of growth and gluconic acid metabolism to a variable profile of iron concentrations was studied in batch and chemostat cultures of glucose-grown yeast-like $A$. pullulans, in order to elucidate the very significant role of iron ions in gluconate metabolism.

\section{MATERIALS AND METHODS}

\section{Microorganism}

Aureobasidium pullulans isolate Nr. 70 (DSM 7085) used in present studies has been isolated from wild flowers (Jülich, Germany) as has been previously described [20].

\section{Pre-Culture}

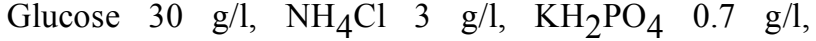
$\mathrm{MgSO}_{4} .7 \mathrm{H}_{2} \mathrm{O} 0.35 \mathrm{~g} / \mathrm{l}, \mathrm{MnSO}_{4} .4 \mathrm{H}_{2} \mathrm{O} 50 \mu \mathrm{g} / \mathrm{l}, \mathrm{FeSO}_{4} .7 \mathrm{H}_{2} \mathrm{O}$ $50 \mu \mathrm{g} / \mathrm{l}, \mathrm{CuSO}_{4} .5 \mathrm{H}_{2} \mathrm{O} 2 \mathrm{mg} / \mathrm{l}, \mathrm{ZnSO}_{4} .7 \quad \mathrm{H}_{2} \mathrm{O} \quad 0.01 \mathrm{~g} / \mathrm{l}$, $\mathrm{CoSO}_{4} .7 \mathrm{H}_{2} \mathrm{O} 4 \mathrm{mg} / \mathrm{l}, \mathrm{H}_{3} \mathrm{BO}_{3} 40 \mathrm{mg} / \mathrm{l}, \mathrm{CaCO}_{3} 5 \mathrm{~g} / \mathrm{l}$, thiamine- $\mathrm{HCl} 2 \mathrm{mg} / 1$, biotin $0.25 \mathrm{mg} / 1,24 \mathrm{~h}$ at $30^{\circ} \mathrm{C}$ and 100 $\mathrm{rpm}$. For further experiments $10 \mu \mathrm{M}$ manganese and iron were taken for inoculum and the concentration of manganese and iron were varied in the fermentation media between 0.25 and $2 \mu \mathrm{M}$ manganese and between 50 and $500 \mu \mathrm{M}$ iron.

\section{Batch Experiments}

Glucose $155 \mathrm{~g} / \mathrm{l}, \mathrm{NH}_{4} \mathrm{Cl} \quad 0.3 \mathrm{~g} / 1, \mathrm{KH}_{2} \mathrm{PO}_{4} 0.3 \mathrm{~g} / \mathrm{l}$, $\mathrm{MgSO}_{4} .7 \mathrm{H}_{2} \mathrm{O} 0.2 \mathrm{~g} / 1, \mathrm{MnSO}_{4} .4 \mathrm{H}_{2} \mathrm{O} 0$ or $10 \mu \mathrm{M}, \mathrm{FeSO}_{4} .7$ $\mathrm{H}_{2} \mathrm{O}$ varied from 0 to $10 \mu \mathrm{M}$, Thiamine- $\mathrm{HCl} 2 \mathrm{mg} / \mathrm{l}$, Biotin $0.025 \mathrm{mg} / \mathrm{l}$. The $\mathrm{pH}$ was automatically attained at 6.5 and the temperature at $30^{\circ} \mathrm{C}$.

\section{CSTR Experiments}

CSTR's cells were grown in a magnetically stirred 1 liter double glass fermenter as has been described previously [4]. The medium contained (g/l): Glucose $360 \mathrm{~g} / 1, \mathrm{NH}_{4} \mathrm{Cl} 3 \mathrm{~g} / \mathrm{l}$, $\mathrm{KH}_{2} \mathrm{PO}_{4} 0.7 \mathrm{~g} / \mathrm{l}, \mathrm{MgSO}_{4} * 7 \mathrm{H}_{2} \mathrm{O} 0.35 \mathrm{~g} / 1, \mathrm{MnSO}_{4} * 4 \mathrm{H}_{2} \mathrm{O} 5$ $\mathrm{mM}, \mathrm{FeSO}_{4} * 7 \mathrm{H}_{2} \mathrm{O} 0.5 \mathrm{mM}, \mathrm{CuSO}_{4} * 5 \mathrm{H}_{2} \mathrm{O} 4 \mu \mathrm{M}(1 \mathrm{mg} / \mathrm{l})$, $\mathrm{ZnSO}_{4} * 7 \mathrm{H}_{2} \mathrm{O} 0.01 \mathrm{~g} / \mathrm{l}, \mathrm{CoSO}_{4} * 7 \mathrm{H}_{2} \mathrm{O} 4 \mathrm{mg} / \mathrm{l}, \mathrm{H}_{3} \mathrm{BO}_{3} 0.04$ $\mathrm{g} / 1, \mathrm{CaCl} 0.1 \mathrm{~g} / 1, \mathrm{NaCl} 0.1 \mathrm{~g} / 1$, citric acid $2.5 \mathrm{~g} / 1, \mathrm{Na}_{2} \mathrm{MoO}_{4} *$ $2 \mathrm{H}_{2} \mathrm{O} 0.2 \mathrm{mg} / \mathrm{l}$, thiamine-HCl $2 \mathrm{mg} / 1$, biotin $0.25 \mathrm{~g} / 1$, pyridoxine-HCl $0.625 \mathrm{mg} / \mathrm{l}$, Ca-D-pantothenate $0.625 \mathrm{mg} / \mathrm{l}$, nicotinic acid $0.5 \mathrm{mg} / \mathrm{l}$. The vitamins and $\mathrm{NH}_{4} \mathrm{Cl}$ were added separately to the autoclaved medium, which was sterilized for $30-60 \mathrm{~min}$ at $121^{\circ} \mathrm{C}$, by sterile filtration (Sartorius, Göttingen, Germany). All chemicals were of highest purity commercially available. The fermentations were carried out at $30^{\circ} \mathrm{C}, 1300 \mathrm{rpm}, 5 \mathrm{l} / \mathrm{h}$ of pure oxygen and $\mathrm{pH} 6.5$ automatically adding a $45 \% \mathrm{NaOH}$ solution.

\section{Analysis}

Optical density $\left(\mathrm{OD}_{660 \mathrm{~nm}}\right)$, dry biomass (filter method) and the concentration of glucose and gluconic acid were determined as has described in previous works [17].

\section{RESULTS}

The effect of iron on growth and gluconic acid of $A$. pullulans DSM 7085 (isolate 70) was investigated under batch and chemostat cultivation (CSTR's) applying constant medium feed rate at RT of about 13 and 18 hours, carried out in 1 liter magnetically stirred glass fermenters on media described in materials and methods. Iron concentrations between 0.25 and $2 \mu \mathrm{M}$ were investigated in batch cultures and 0.1-2 $\mathrm{mM}$ iron in CSTRs.

\section{Batch Experiments}

Because the gluconic acid process using A. pullulans was still poorly investigated the effect of varying iron and ( 0 or $10 \mu \mathrm{M})$ and manganese concentration $(0-2000 \mu \mathrm{M})$ was initially examined in preliminary orientation batch experiments, carried out in $1 \mathrm{~L}$ glass fermenter with $500 \mathrm{ml}$ working volume at $30^{\circ} \mathrm{C}$ und $\mathrm{pH} 6.5,1000 \mathrm{rpm}$ and 51 pure oxygen $/ \mathrm{h}$, using a defined mineral medium described in material and methods. The $\mathrm{pH}$ was controlled automatically by the addition of $4 \mathrm{~N} \mathrm{NaOH}$.

It is possible to control growth and gluconic acid formation of A. pullulans by varying iron and manganese concentration. The highest product concentration and OD were reached in experiments with a medium containing both, iron and manganese as compared with experiments either without iron or manganese (Table 1). An OD of only 0.2 and $2.3 \mathrm{~g} / 1$ gluconic acid were reached after $24 \mathrm{~h}$ in experiment without manganese and iron in comparison to OD of 0.55 and 11.1 $\mathrm{g} / \mathrm{l}$ gluconic acid reached with $10 \mu \mathrm{M}$ iron and $10 \mu \mathrm{M}$ of manganese. Only $18.7 \mathrm{~g} / 1$ and an OD of 0.52 were reached after $48 \mathrm{~h}$ without $\mathrm{Fe}$ and $\mathrm{Mn}$, compared with $127.2 \mathrm{~g} / \mathrm{l}$ and $6.03 \mathrm{OD}$ obtained with $10 \mu \mathrm{M} \mathrm{Mn}$ and $10 \mu \mathrm{M}$ Fe. Very high molar selectivities were obtained under iron and manganese limitation and in experiments with $10 \mu \mathrm{M} \mathrm{Fe}$ and $10 \mu \mathrm{M} \mathrm{Mn}$, approaching $98 \%$ without $\mathrm{Fe}$ and $\mathrm{Mn}$ due to very low pellet forming biomass. $32 \mathrm{~g} / 1$ gluconic acid were produced after $54 \mathrm{~h}$ without Fe and Mn compared with $147.1 \mathrm{~g} / \mathrm{l}$ reached with $0 \mu \mathrm{M}$ Fe und $10 \mu \mathrm{M}$ Mn and 118,9 g/l obtained with 10 $\mu \mathrm{M}$ iron und $0 \mu \mathrm{M} \mathrm{Mn}$. Further increase of manganese concentration accelerated gluconic acid and biomass formation even in absence of iron displaying an optimum.

Furthermore, the effect of iron on growth and gluconate formation was investigated in batch experiments at a variable iron concentration between 0.05 and $0.5 \mathrm{mM}$. Whereas OD increased with increasing $\mathrm{Fe}$ differences in gluconic acid production were insignificant, reaching the highest gluconic acid concentration of $160 \mathrm{~g} / \mathrm{l}($ after $100 \mathrm{~h})$ with $0.1 \mathrm{mM} \mathrm{Fe}$ at an OD of 7.9. 
Table 1. Manganese and Iron Effect on Gluconic Acid Formation by A. pullulans

\begin{tabular}{|c|c|c|c|c|c|c|c|}
\hline \multicolumn{2}{|c|}{ Cultivation time (h) } & 24 & 28 & 48 & 24 & 28 & 48 \\
\hline 0 & 0 & 0.21 & 0.22 & 0.52 & 2.3 & 5.0 & 19.6 \\
\hline 0 & 10 & 0.45 & 0.71 & 1.85 & 10.9 & 23.7 & 88.8 \\
\hline 10 & 10 & 0.55 & 1.52 & 6.03 & 11.1 & 30.2 & 127.2 \\
\hline 10 & 250 & 3.95 & 4.99 & 6.32 & 29.1 & 40.3 & 69.2 \\
\hline 10 & 500 & 3.59 & 4.36 & 5,77 & 44.3 & 61.8 & 129.3 \\
\hline 10 & 2000 & 3.04 & 3.82 & 4.08 & 35.7 & 58.4 & 112.6 \\
\hline
\end{tabular}

\section{CSTRs Experiments}

The effect of iron on growth and gluconic acid production was investigated in CSTR experiments at $30^{\circ} \mathrm{C}$ and $\mathrm{pH}$ 6.5 with a medium as described in materials and methods containing $3 \mathrm{~g} / \mathrm{l} \mathrm{NH} \mathrm{N}_{4} \mathrm{Cl}$ and $360 \mathrm{~g} / \mathrm{l}$ glucose. Fig. (1) shows the effect of varying iron concentration on growth and gluconic acid production of A. pullulans at $13 \mathrm{~h} \mathrm{RT}$.

More than $190 \mathrm{mg} / \mathrm{l}$ residual nitrogen was determined in all of CSTR experiments at $13 \mathrm{~h} \mathrm{RT} ; 197 \mathrm{mg} / \mathrm{l}$ nitrogen at $0.1 \mathrm{mM}$ and $201 \mathrm{mg} / \mathrm{l}$ at $2 \mathrm{mM}$ iron. Insignificant differences were observed in biomass formation ranging between $7.3 \mathrm{~g} / 1$ biomass at $0.1 \mathrm{mM}$ and $6.9 \mathrm{~g} / \mathrm{l}$ at $2 \mathrm{mM}$ iron (Fig. 1). No correlation was observed between the optical density and biomass concentration at varying iron concentration, indicating the strong influence of iron concentration on cell morphology of dimorphic (single or multicellular) yeast-like fungus $A$. pullulans, meaning that single cells have a higher optical density. The higher OD/biomass at lower iron con- centrations indicates the occurrence of smaller single cells (higher total cell surface, higher OD).

At $13 \mathrm{~h} \mathrm{RT}$, the highest formation rate of the generic product of $16.8 \mathrm{~g} /(1 * \mathrm{~h})$, specific gluconic acid productivity $\left(\mathrm{m}_{\mathrm{p}}\right)$ of $2.5 \mathrm{~g} /(\mathrm{g} * \mathrm{~h})$ and gluconic acid concentration of 223.3 $\mathrm{g} / \mathrm{l}$ were obtained at $1 \mathrm{mM}$ iron. Comparatively, only $182 \mathrm{~g} / \mathrm{l}$ (81.5\%), $14.5 \mathrm{~g} /(1 * \mathrm{~h}) \mathrm{Rj}$ and $1.82 \mathrm{~g} /(\mathrm{g} * \mathrm{~h}) \mathrm{mp}$ were reached at $0.1 \mathrm{mM}$ and $215.7 \mathrm{~g} / \mathrm{l}(96.6 \%), 15.66 \mathrm{~g} /(1 * \mathrm{~h}) \mathrm{Rj}$ and 2.27 $\mathrm{g} /(\mathrm{g} * \mathrm{~h}) \mathrm{mp}$ at $2 \mathrm{mM}$ iron. Surprisingly, major variations were found in product selectivity as a function of iron concentration at $13 \mathrm{~h} \mathrm{RT}$ and incomplete conversion of glucose. Product selectivity increased continuously by increasing iron concentration and showing a saturation effect reached a maximum of about $98 \%$ at $2 \mathrm{mM}$ and $76.2 \%$ conversion, compared with only $84.3 \%$ at $0.1 \mathrm{mM}$. At iron concentration higher than $0.5 \mathrm{mM}$, selectivity was above $90 \%$ (Fig. 2).

No significant differences were observed in gluconate concentration at $18 \mathrm{~h} \mathrm{RT}$ (Fig. 3 ) in contrast to $13 \mathrm{~h}$, because

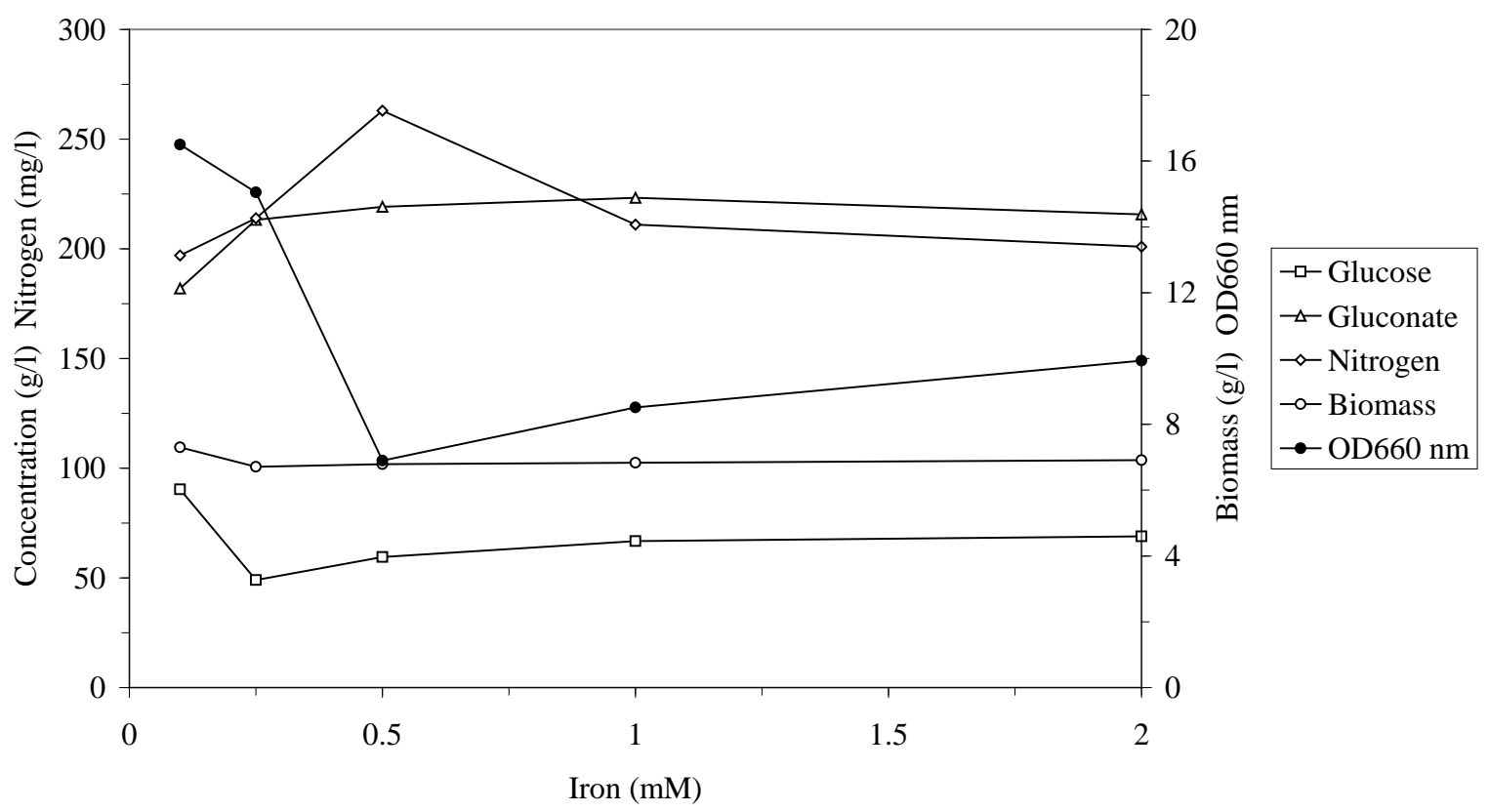

Fig. (1). Iron effect on growth and gluconic acid production at about $13 \mathrm{~h} \mathrm{RT}\left(3 \mathrm{~g} / \mathrm{N} \mathrm{NH}_{4} \mathrm{Cl}, 360 \mathrm{~g} / \mathrm{lglucose}, 5 \mathrm{mM} \mathrm{Mn}, 30^{\circ} \mathrm{C}\right.$ and $\left.\mathrm{pH} 6.5\right)$. 


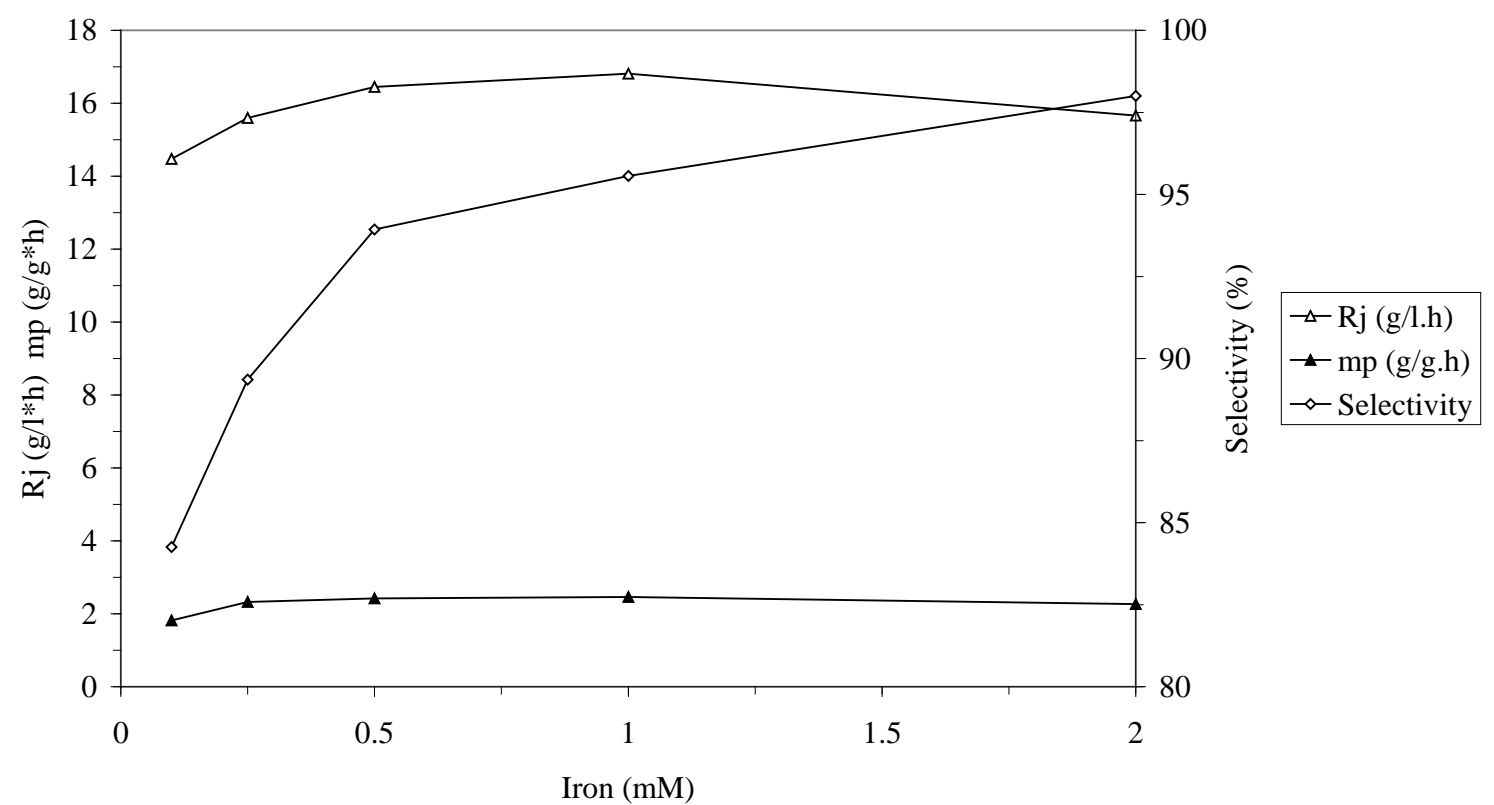

Fig. (2). Iron effect on $\mathrm{R}_{\mathrm{j}}, \mathrm{m}_{\mathrm{p}}$ and selectivity at a residence time of about $13 \mathrm{~h}\left(3 \mathrm{~g} / 1 \mathrm{NH}_{4} \mathrm{Cl}, 360 \mathrm{~g} / \mathrm{l} \mathrm{glucose}, 5 \mathrm{mM} \mathrm{Mn}, 30^{\circ} \mathrm{C}\right.$ and $\left.\mathrm{pH} 6.5\right)$.

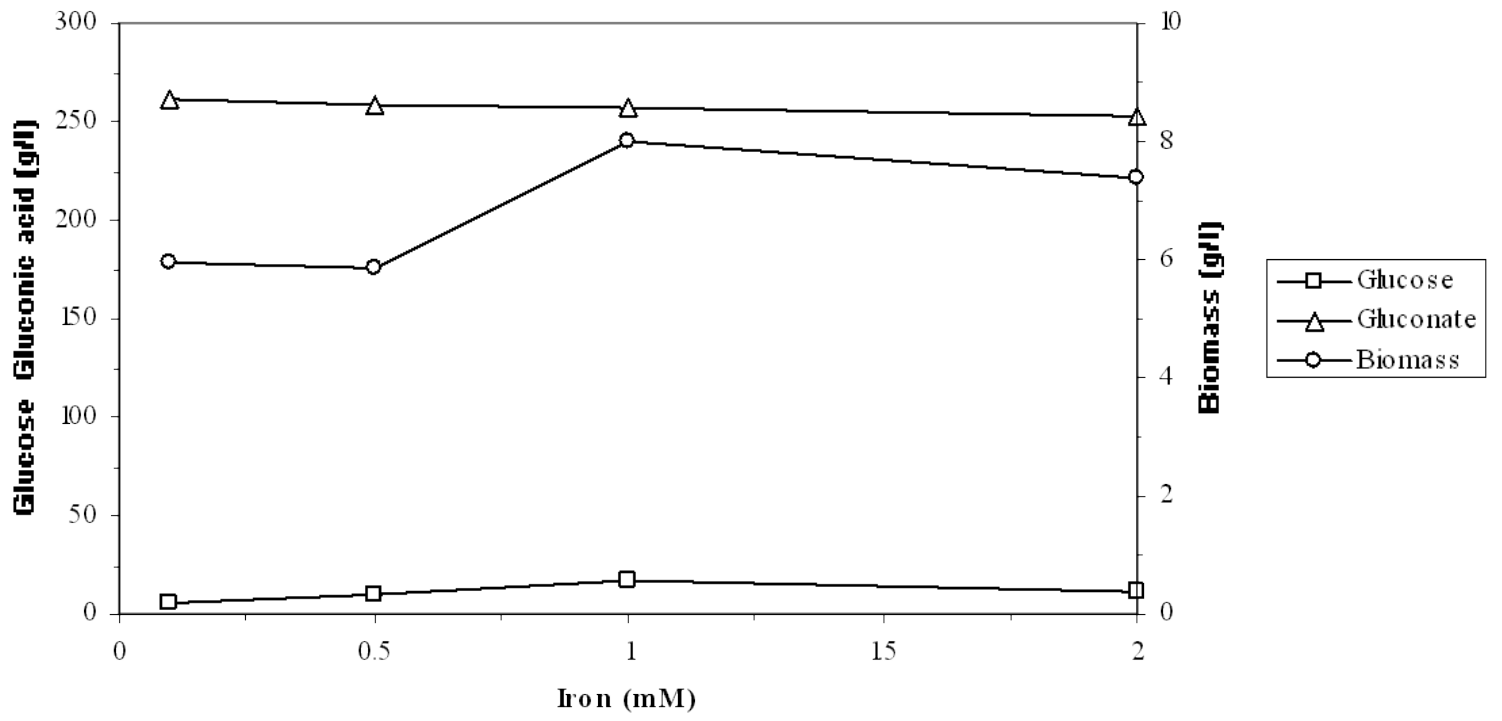

Fig. (3). Iron effect on growth and gluconic acid production at about $18 \mathrm{~h} \mathrm{RT} \mathrm{(3} \mathrm{g/l} \mathrm{NH} 4 \mathrm{Cl}, 360 \mathrm{~g} / \mathrm{l} \mathrm{glucose}, 5 \mathrm{mM} \mathrm{Mn}, 30^{\circ} \mathrm{C}$ and $\left.\mathrm{pH} 6.5\right)$.

of the nearly complete consumption of glucose. Optimization CSTRs studies are supposed to be operated at about $80 \%$ of conversion (g converted glucose/g feed glucose). XT diagrams as a function of varying residence time or dilution rate have been published in previous work [16].

The highest biomass of $8 \mathrm{~g} / \mathrm{l}$ was achieved at $18 \mathrm{~h} \mathrm{RT}$ with $1 \mathrm{mM}$ iron, compared with $5.95 \mathrm{~g} / 1$ reached with 0.1 $\mathrm{mM}$. More than $250 \mathrm{~g} / \mathrm{l}$ gluconic acid was produced with all of investigated iron concentrations, reaching the highest concentration of $260.9 \mathrm{~g} / 1$ and a $\mathrm{Rj}$ of $14.5 \mathrm{~g} /\left(1^{*} \mathrm{~h}\right)$ at $0.1 \mathrm{mM}$ iron compared with $252.4 \mathrm{~g} / \mathrm{l}$ and $14.02 \mathrm{~g} /(1 * \mathrm{~h})$ measured at $2 \mathrm{mM}$ (Fig. 3). Selectivity dropped with increasing iron concentration at $18 \mathrm{~h}$, because of intensifying nitrogen limitation which causes byproduct formation, like pullulan and other organic acids (e.g. fumaric acid). Fumaric acid concentra- tions between $0.026 \mathrm{mM}$ (presence of nitrogen, $6.8 \mathrm{~h} \mathrm{RT}$ ) and $15.2 \mathrm{mM}$ (absence of nitrogen, $50.1 \mathrm{~h} \mathrm{RT}$ ) have been found as a byproduct in gluconic acid production by $A$. pullulans as a function of RT and nitrogen limitation (data not shown here). A molar selectivity of $85.1 \%(92.7 \% \mathrm{~g} / \mathrm{g})$ was calculated at $1 \mathrm{mM}$ and $82 \%$ at $2 \mathrm{mM}$ iron $(89.3 \% \mathrm{~g} / \mathrm{g})$. Glucose was not consumed completely and a residual glucose of $16.5 \mathrm{~g} / \mathrm{l}$ was measured at $2 \mathrm{mM}$ iron and about $95 \%$ conversion.

\section{DISCUSSION}

The development of any new multi-step biotechnological process requires three basic steps, namely: the identification and characterization of a suitable biological system (microorganism, biocatalyst), the increase of bioreactor productiv- 
ity by sophisticated media optimization and adaptation of fermentation technology to the developed process and downstream processing (cell separation by centrifugation or ultrafiltration, product separation, evaporation and drying).

Chemostat cultures are dynamic systems for sophisticated medium optimization and process development, in where single parameters can be investigated in detail under steady state conditions, identifying and optimizing various optima for microbial growth and production. Very high glucose concentrations can be applied in feeding medium because of the wash out effect of chemostat due to continuous microbial glucose consumption, resulting to low residual steady state glucose concentrations. Alternatively, high initial glucose concentrations slow down the growth of $A$. pullulans in batch cultures. Additionally, chemostat results obtained under steady state conditions are easily reproducible and compensation effects between growth and production are detected based on volumetric and biomass-specific productivity of the generic product $[4,16]$.

Enzymatic glucose conversion to gluconic acid is enabled either by fungal enzyme glucose oxidase or bacterial glucose dehydrogenase (e.g. bacteria such as Gluconobacter, Acetobacter). The enzymatic complex glucose oxidase/catalase is present in several microorganisms belonging e.g. to the classes Aspergillus and Penicillium or alternative in yeastlike mold Aureobasidium pullulans (Pullularia pullulans). Bacteria like Acetobacter and Gluconobacter use different mechanisms for converting glucose into gluconic acid. $G$. oxydans contains two types of glucose dehydrogenase which convert glucose into gluconolactone without the formation of hydrogen peroxide. Enzymes derived from cloned genes of GMO organisms may also be involved in the production of gluconic acid production or alternative economical host systems can be developed [7, 15, 21, 22]. Strain improvement has been reported to be an essential step in developing industrial microbial production processes [23].

Yeast-like mould A. pullulans is well known for pullulan formation, a polysaccharide [24-28]. About gluconic acid's production by $A$. pullulans (formerly known as Dematium or Pullularia pullulans) has been previously reported using various carbon sources [29-32], however it hasn't been considered as a potential gluconic acid producer before. No information was available regarding fermentation conditions or process optimization and development and those pioneer works were mainly restricted to shake flask experiments [16]. Little is known about the regulatory mechanisms of gluconic acid production by yeast like mold A. pullulans, which has been shown to be a superior gluconic acid producer $[4,7,15-17,33]$. A. pullulans isolate 70 (DSM 7085) was isolated from wild flowers in Germany and no genetic works were carried out, in order to increase gluconic acid production, in opposite of today's industrial gluconic acid production, which uses improved mutant strains of several generations, predominantly recycled mycelia of Aspergillus niger, or Gluconobacter suboxidans in discontinuous submerse fermentations [34-36]. Today's sodium gluconate fermentation using A. niger in submerse fermentation bases on the process developed by [14].

The response of growth and gluconic acid metabolism to a variable profile of different iron concentrations was studied with glucose-grown batch and chemostat cultures of yeast like mold A. pullulans; the emphasis was focused on the physiological parameters of yeast growth and gluconic acid production, demonstrating the tremendous significance of iron ions in this process. In preliminary orientation batch cultures, iron as well as manganese ions have been identified to be critical nutrients, strongly influencing growth and gluconic acid formation in A. pullulans, whereby manganese showed a stronger effect than iron. Serving as cofactors of essential enzymes for the production of gluconic acid (Glucose-Oxidase, Catalase) iron as also manganese are significant trace elements for optimal gluconate production in $A s$ pergillus niger and $A$. pullulans. In commercial fermentations they are added into bioreactor in undefined amount with maize steep water and other medium compounds.

It is also well known that iron is the integral component of many metalloenzymes; such as aconitate-hydratase, catalase, peroxidases and components of mitochondrial electron transfer chain $[37,38]$ and often iron concentration was used as variable factor to control microbial metabolism [39-41]. Iron concentration had in accordance to batch experiments no relevant effect on the growth of $A$. pullulans. A very strong iron effect on gluconate production was observed in batch cultures at the lower concentrations of $0-10 \mu \mathrm{M}$. Substantial differences of iron effect on gluconic acid fermentation occurred at the lower RT (lower conversion) of $13 \mathrm{~h}$, whereas no significant differences were observed in gluconate production at $18 \mathrm{~h}$ RT, because of the nearly complete consumption of glucose. Optimization CSTRs studies are supposed to be operated at about $80 \%$ conversions ( $\mathrm{g}$ converted glucose/g feed glucose) for identifying the real effects. A surprisingly high particular requirement of iron ions (0.5-3.0 mMol at $3 \mathrm{~g} / 1 \mathrm{NH}_{4} \mathrm{Cl}$ ) has been detected for profitably performing gluconic acid fermentation in A. pullulans, displaying an optimum iron concentration between 1-2 mM for product concentration, product yield, selectivity, $\mathrm{R}_{\mathrm{j}}$ and $\mathrm{m}_{\mathrm{p}}$. With increasing iron concentration from 0.1 to $2 \mathrm{mM}$, product selectivity increased continuously showing a saturation behavior and reached almost $100 \%$. A more intensive respiration (respiration chain) as well as byproduct formation (e.g. fumaric acid and pullulan formation) are eventually the main reasons for low selectivity at lower iron concentrations. For example, [42] reported that iron supply enhances mycelial growth form of dimorphic A. pullulans and decreases pullulan formation. Mycelial form of $A$. pullulans favors gluconic acid formation in our investigations, suppressing pullulan formation, instead, showing the relationship between morphology and gluconic acid production.

The increase of $\mathrm{mp}$ and and $\mathrm{Rj}$ at almost constant biomass at $13 \mathrm{~h} \mathrm{RT}$ at increasing iron concentration up to 1 $\mathrm{mM}$, indicates that iron stimulates synthesis or/and activity of glucose oxidizing enzymes in A. pullulans. [43] reported about the stimulation of glucose oxidase synthesis in $A$. niger by the supply of iron sulfate and $\mathrm{KCl}$. Similar effects found $[44,45]$ in Penicillium strains. [45] as well as [46] reported on the other side that supply of $0.001 \% \mathrm{FeSO}_{4} * 7 \mathrm{H}_{2} \mathrm{O}$ or of 2.1-40.4 $\mu \mathrm{M}$ iron didn't stimulate production of calcium gluconate by $P$. chrysogenum or with $A$. niger, respectively. Furthermore, presence of iron has been reported to favor, in addition to sodium salts, accumulation of oxalic acid and of yellow-green pigments in mycelia of $A$. niger, affecting product separation [47]. 
The discrepancy between biomass and OD can be explained by the influence of iron on dimorphic growth behavior of yeast-like A. pullulans. Single cell growth (higher total cell surface, higher OD) promotes pullulans formation instead of gluconic acid. Nitrogen and Iron limitation have been reported to enhance pullulans production in A. pullulans. Iron limitation possibly promotes fumaric acid byproduction as well.

RT is also of major importance for optimum production and must be taken into consideration, since gluconic acid is partly utilized at long RTs, because of almost complete glucose consumption (100\% conversion). This is also confirmed by the reduction of selectivity at increasing iron concentration at $21 \mathrm{~h} \mathrm{RT}$, due to almost complete glucose consumption and progressive product redirection or reconsumption.

The present results of very high gluconic acid concentrations reached at very low RT $(13 \mathrm{~h})$ by free growing cells of A. pullulans are the best known that have been published in the international bibliography, encouraging the use of $A$. pullulans processes for future industrial applications in gluconic acid business as innovative alternatives to the discontinuous fungi processes.

\section{CONCLUSIONS}

Yeast-like A. pullulans offers the positive characteristics of both groups of eucaryotic (fungi and yeasts) and prokaryotic microorganisms (bacteria) at once, enabling a continuous process operation by free growing cells running at very high glucose and product titers. Medium optimization carried out in chemostat resulted in strong increase of yield and selectivity, productivity and product concentration at very short residence times. Present results of very high gluconic acid concentrations reached at very low RT $(13 \mathrm{~h})$ by free growing cells of A. pullulans without any biomass retention are the best known that have been published in the international bibliography, encouraging the use of new Aureobasidium pullulans processes $[4,5,16,17,20,33]$ for future industrial applications in gluconic acid business as innovative alternatives to the discontinuous fungi processes of the last 100 years. Based on our deep investigations on the influence of important fermentation parameters on gluconic acid production by A. pullulans, such as $\mathrm{pH}$, temperature, air saturation, medium composition, residence time, biomass retention, cascading of two fermenters etc., further investigations would accelerate the continuous and discontinuous production of gluconic acid decreasing production costs to minimal levels. Present results show nature's latent potential for still unknown high producing microbial wild strains as a comparison to extensive publicity of genetic engineering research and development for future applications in gluconic acid research.

\section{ACKNOWLEDGEMENT}

We thank gratefully Prof. Dr. Christian Wandrey (Director of the Institute of Biotechnology 2 of Research Center Jülich, RCJ, Germany) for his helpful advices and great support.

The work has been carried out at the Institute of Biotechnology 2 of Research Center Jülich (formerly known as Nuclear Research Center Jülich, Germany) and was partially financed by Haarmann \& Reimer, a daughter company of the company Bayer, Leverkusen, Germany and has been continued at the Pythia Institute of Biotechnology (Greece).

\section{ABBREVIATIONS AND DEFINITIONS}

$\mathrm{R}_{\mathrm{j}}$

$=$ Formation rate of the generic product, $\mathrm{g}$ gluconic acid/(1*h) (volumetric productivity)

$\mathrm{m}_{\mathrm{p}} \quad=$ Specific gluconic acid productivity, $\mathrm{g}$ gluconic acid/(g biomass*h) (Biomass specific productivity)

RT $\quad=$ Residence time $(\mathrm{h})$

CSTR $=$ Continuous stirred-tank reactor

$\mathrm{OD}$

$=$ Optical density

Selectivity $=$ G product/g converted glucose $(\%)$

Yield $\quad=\mathrm{G}$ product $/ \mathrm{g}$ initial glucose $(\%)$

Conversion $=\mathrm{G}$ converted glucose/g initial glucose $(\%)$

$\mathrm{XT}$ diagram $=$ Parameters as a function of residence time

\section{REFERENCES}

[1] Bermejo F, Brañas G. Spectrophotometric determination of manganese II) with gluconic acid. Microchim Acta 1971; 59(3): 48993.

[2] Hustede H, Haberstroh HJ, Schinzig E. Gluconic acid. In: ULLMANN'S Encyclopedia of industrial chemistry. Eds. Weinheim 1989; vol. A 12: 449-56.

[3] Znad H, Markos J, Bales V. Production of gluconic acid from glucose by Aspergillus niger: growth and non-growth conditions. Process Biochem 2004; 39(11): 13415.

[4] Anastassiadis S, Aivasidis A, Wandrey C. Process optimization for continuous gluconic acid fermentation by isolated yeast-like strains of Aureobasidium pullulans. Biotechnol Bioeng 2005; 91(4): 494501.

[5] Ramachandran S, Fontanille P, Pandey A, et al. Gluconic Acid: Properties, Applications and Microbial Production. Food Technol Biotechnol 2006; 44(2): 185-195.

[6] Singh OV, Kumar R. Biotechnological production of gluconic acid: future implications. Appl Microbiol Biotechnol 2007; 75(4): 71322 .

[7] Anastassiadis S, Morgunov IG. Gluconic acid production. Recent Patents Biotechnol 2007; 1(2): 167-80.

[8] Heinrich M, Rehm HJ. Formation of gluconic acid at low pH values by free and immobilized Aspergillus niger cells during citric acid fermentation. Eur J Appl Microbiol Biotechnol 1982; 15: 8892.

[9] Hartmeier W, Döppner T. Preparation and properties of mycelium bound glucose oxidase co-immobilized with excess catalase. Biotechnol Lett 1983; 5(11): 743-8.

[10] Szajani B, Molnar A, Klamar B, et al. Preparation, characterization, and potential application of an immobilized glucose oxidase. Appl Biochem Biotechnol 1987; 14: 37-47.

[11] Nakao K, Kiefner A, Furumoto K, et al. Production of gluconic acid with immobilized glucose oxidase in airlift reactors. Chem Eng Sci 1997; 52(21-22): 4127-33.

[12] Sankpal NV, Joshi AP, Sutar II, et al. Continuous production of gluconic acid by Aspergillus niger immobilized on a cellulosic support: study of low $\mathrm{pH}$ fermentative behaviour of Aspergillus niger. Process Biochem 1999; 35: 317-25.

[13] Sankpal NV, Kulkarni BD. Optimization of fermentation conditions for gluconic acid production using Aspergillus niger immobilized on cellulose microfibrils. Process Biochem 2002; 37(12): 1343-50.

[14] Blom RH, Pfeifer VF, Moyer AJ, et al. Sodium gluconate production, Fermentation with Aspergillus niger. Ind Eng Chem Res 1952; 44(2): 435-40. 
[15] Anastassiadis S, Aivasidis A, Wandrey C. Process for the production of gluconic acid with a strain of Aureobasidium pullulans (DE BARY) Arnaud. US Patent No. 5,962,286 (Oct. 5, 1999).

[16] Anastassiadis S, Aivasidis A, Wandrey C. Continuous gluconic acid production by isolated yeast-like mould strains of Aureobasidium pullulans. Appl Microbiol Biotechnol 2003; 61(2): 110-7.

[17] Anastassiadis S, Rehm H-J. Continuous gluconic acid production by the yeast-like Aureobasidium pullulans in a cascading operation of two bioreactors. Appl Microbiol Biotechnol 2006; 73(3): 541-8.

[18] Magnuson JK, Lasure LL. Organic Acid Production by Filamentous Fungi. Advances in Fungal Biotechnology for Industry, Agriculture, and Medicine. Edited by Jan and Lene Lange, Kluwer Academic/Plenum Publishers, 2004: 307-40.

[19] Rehm H-J. Industrielle Mikrobiologie, $2^{\text {nd }}$ ed. Springer, Berlin Heidelberg New York, 1980.

[20] Anastassiadis S. Kontinuierliche Fermentation von Glucon- und Citronensäure mit hefeähnlichen Pilzen und Hefen. Ph.D. Thesis, Westfälische Wilhelms-Universität Münster, Germany, 1994.

[21] Liu Wen-Hsiung et al. Enzymatic Oxidation of Glucose via Crab Chitin Immobilized Glucose Oxidase and Catalase. Proc Natl Sci Counc Repub China 1980; 4(3): 338-344 (referred in 22).

[22] Vroemen AJ, Beverini M. Enzymatic production of gluconic acid or its salts. US Patent 5,897,995 (1999).

[23] Petruccioli M, Piccioni P, Federici F. Glucose oxidase overproduction by the mutant strain M- 80.10 of Penicillium variabile in a benchtop fermenter. Enzyme Microbial Technol 1997; 21: 458-62.

[24] Catley BJ. Role of $\mathrm{pH}$ and nitrogen limitation in the elaboration of extracellular polysaccharide pullulan by Pullularia pullulans. Appl Microbiol 1971; 22(4): 650-4

[25] Catley BJ. Pullulan elaboration, an inducible system of Pullularia pullulans. FEBS Lett 1972; 20(2): 174-6.

[26] Catley BJ. Microbial polysaccharides and polysaccharoses. In: Berkeley RCW, (Gooday GW and Ellwood DC, Eds.). Special publications of the society for general microbiology \#3, Academic Press, London, 1979.

[27] Catley BJ. The extracellular polysaccharide, pullulan, produced by Aureobasidium pullulans: A relationship between elaboration rate and morphology. J Gen Microbiol 1980 ; 120: 265-8.

[28] Kristiansen B, Charley RC, Seviour B, Harvey L, Habeeb S, Smith JE. Over-production of metabolites by filamentous fungi. In: Overproduction of microbial products. Krumphanzl V, Sikyta B, Vanek Z, Eds. Academic press, London, New York, Paris, San Diego, San Francisco, Sao Paulo, Sydney, Tokyo, Toronto, 1982: 195-210.

[29] Perwozvansky WW. Über das Verhalten von Hefepilzen und einigen Hyphomycetes-Arten zu Chinansäure. Microbiology. Zentralblatt für Bakteriologie, Parasitenkunde und Infektionskrankheiten. 2. Abt. Jena, 1930; 81: 372-91.

[30] Fujita K, Ueda S. Report at the Annual Meeting of Agr. Chem. Soc. Japan, Fukuoka, on Apr. 1, 1961 (Referred in: Takao and Sasaki, 1964).

[31] Takao S, Sasaki Y. Gluconic acid fermentation by Pullularia pullulans Part I. Screening of gluconic acid-producing strains and some conditions for its production. Agr Biol Chem 1964; 28(11): 752-6.

[32] Sasaki Y, Takao S (1970). Gluconic acid fermentation by Pullularia pullulans II. Acid production from various carbon sources. J Ferment Technol 1970; 48: 368-73.
[33] Anastassiadis S, Rehm H-J. Continuous gluconic acid production by biomass retention of Aureobasidium pullulans. Electronic J Biotechnol 2006; 9(5).

[34] Das A, Nandi P. Improved production of calcium gluconate by treatment with ultraviolet rays. Sci Cult (Calcuta) 1969; 35(11): 642-4.

[35] Bigelis R. Industrial products of biotechnology: Application of gene technology. In: Biotechnology (Rehm HJ and Reed G, eds.) chapter 6a, Gene Technology. Jacobson GK, Jolly SO, Eds. Weinheim 1989; Vol. 7b: 230-59.

[36] Röhr M, Kubicek CP, Kominek J. Gluconic acid. In: Biotechnology. Rehm HJ, Reed G, Eds. Verlag Chemie, Weinheim-Deerfield Beach/Florida-Basel, 1983; Vol. 3: 456-65.

[37] Coughlan MP. The role of iron in microbial metabolism. Sci Prog Oxf 1971; 59: 1-23.

[38] Anastassiadis S, Kamzolova SV, Rehm H-J, Morgunov IG. Comparative Study of the Effect of Iron on Citrate-producing Yeast Growing on Different Substrates. Book Chapter at "Communicating Current Research and Educational Topics and Trends in Applied Microbiology, FORMATEX Microbiology series 2007; No. 1, Vol. 1 (Book)" Industrial and Food Microbiology, p. 308-314, Mendez-Vilas A, Ed. ISBN-13: 978-13: 978-84-611-9422-3. http: // www.formatex.org/microbio/pdf/Pages308-314.pdf

[39] Il'chenko AP, Singkh NN, Shishkanova NV, Finogenova TV. Influence of initial ethanol concentration and $\mathrm{Zn}^{2+}$ and $\mathrm{Fe}^{2+}$ ratio in the cultivation medium on the respiration and functioning of the mitochondrial respiratory chain in the yeast Torulopsis candida. Mikrobiologiya (Russ) 1996; 65(3): 305-12.

[40] Finogenova TV, Kamzolova SV, Dedyukhina EG, et al. Biosynthesis of citric and isocitric acids from ethanol by mutant Yarrowia lipolytica $\mathrm{N} 1$ under continuous cultivation. Appl Microbiol Biotechnol 2002; 59: 493-500.

[41] Kamzolova SV, Shishkanova NV, Morgunov IG, Finogenova TV. Oxygen requirements for growth and citric acid production of Yarrowia lipolytica. FEMS Yeast Res 2003; 3(2): 217-22.

[42] Reeslev M, Nielsen JC, Jorgensen BB. Nutritional dependent dimorphism in the exopolysaccharide producing deuteromycete Aureobasidium pullulans polysaccharide e.g. pullulan production; effect of trace element in culture medium. Eur Congr Biotechnol 1990; 5 Meet.: 1053-6.

[43] Munk V, Paskova J, Hanus J. Glucose oxidase of Aspergillus niger I. Factors influencing glucose oxidase activity in submerged cultivation of Aspergillus niger on synthetic medium. Folia Microbiol 1963; 8: 203-214, Praha.

[44] Pokrovsaya NV, Novikova LM, Finogenova TV. Production of glucose oxidase by some molds. Microbiology (USSR) 1963; 31: 639.

[45] Ambekar GR, Thadani SB, Doctor VM. Production of calcium gluconate by Penicillium chrysogenum in submerged culture. Appl Microbiol 1965; 13(5): 713-9.

[46] Rao DS, Panda T. Comparative analysis of gluconate and sodium gluconate techniques for the production of gluconic acid by Aspergillus niger". Bioprocess Engin 1993; 8: 203-7.

[47] Lockwood LB. Production of organic acids by fermentation. In: Microbial Technology (Kap. 11), Peppler HJ, Perlman D, Eds. Academic Press, New York, 1979; Vol. 1: 355-87. 